\title{
Clues about ageing in The Thursday Murder Club
}

\author{
Elizabeth Murphy ${ }^{1} \cdot$ Desmond O'Neill $^{1}$ (1)
}

Received: 8 April 2021 / Accepted: 31 May 2021 / Published online: 11 June 2021

(c) European Geriatric Medicine Society 2021

Keywords Ageing $\cdot$ Humanities $\cdot$ Nursing home $\cdot$ Assisted living facilities

Our perceptions of ageing are shaped by the media we consume. Too often this is negative, promoting ageist tropes: older adults are portrayed as frail, confused and vulnerable. This is reflected in medical literature which can pathologize ageing as disease and emphasize age-related losses [1]. Even the model of 'successful ageing' has its detractors: successful ageing as avoidance of disability implies that the opposite is a failure [2], creating a dichotomy that stigmatizes the accumulation of comorbidities as a failing on the part of the older adult. There is little recognition of the longevity dividend, the concept that by virtue of their accumulated wisdom, skills and talents, older adults have much to contribute to our social environment [3].

The negative perceptions may be aggravated in the context of nursing home care. It is important that geriatricians, as guardians of the longevity dividend, generate a focus on life in congregated settings that emphasises that life in nursing homes is for living and not just for dying. Thoughtful reflection on depictions of life in nursing homes can provide a basis for sharing concepts and ideas. Some, such as the American novel Simon's Night [4] continue to portray a grim custodial picture of nursing home life. A more imaginative view is evident in Cortex, a French movie where a detective with Alzheimer's disease helps to solve a murder mystery, an approach presenting him as an active agent struggling to retain autonomy [5].

This theme of murder mystery and congregated living is revisited in The Thursday Murder Club [6], a jaunty murder mystery set in a fictional retirement community and associated nursing home called Coopers Chase. The author, Richard Osman, is a successful British gameshow host and

Desmond O'Neill

doneill@tcd.ie

1 Centre for Ageing, Neuroscience and the Humanities, Trinity Centre for Health Sciences, Trinity College Dublin, Tallaght University Hospital, Dublin D24 NR0A, Ireland acknowledges that he was inspired by visiting a similar community 'full of extraordinary people with extraordinary stories.'

Four residents gather weekly to review old police files and crack cases, but when a local builder is bludgeoned, they turn their hand to detecting with great panache. The characters are warmly realised: Joyce, an observant nurse, Ibrahim the octogenarian psychiatrist, and ex-trade unionist and famous firebrand Ron are led by Elizabeth, retired international woman of mystery. She has mysterious connections from her time in East Germany and claims to still have an active licence to drive a tank! As bodies pile up, the Club is drawn in, confronting suspects and out-investigating the local police.

The Thursday Murder Club is a cheerful crime novel that provides a charming example of the longevity dividend. The experience of the ageing protagonists, in particular the enterprising Elizabeth and the tricks she picked up behind the Iron Curtain, more than outweigh the occasional cataract or dodgy hip. They are a match for any shady property developers, drug smugglers or priest impersonators that threaten to disturb their peaceful idyll. They enjoy a sense of community, and a freedom denied to their younger relatives: 'after a certain age, you can pretty much do whatever takes your fancy. No one tells you off, except your doctors and your children'.

The members of the Club are aware of the stereotypes surrounding ageing and play into them cheerfully when needed. Elizabeth impersonates a tearful nun whose bag has been stolen to bribe a constable. More conniving residents feign dementia to shoplift salmon from a supermarket. Pretending confusion is as comfortable a part of the investigators' arsenal as plying DCI Hudson, a hapless local detective, with cake and sherry to persuade him to share information.

But despite a rosy look at the pleasures of later life, the model of ageing as failure still is apparent. Dementia is the greatest fear of all the residents; 'memory was the bogeyman 
that stalked Cooper's Chase... Every so often you would wake at night in a cold dread'. So fearful of memory loss is Elizabeth that she compulsively memorises license plates, challenging herself to recall them later. As her husband becomes increasingly disorientated, she grinds temazepam into his tea and confines him to their apartment, preventing anyone from discovering his dementia. To be brought to Willows, the local nursing home, is the great terror: a squat building constantly lit in fluorescent lights, it represents a stain on the happiness that permeates Coopers Chase. Amidst crisp gardens of septuagenarians drinking wine and playing bowls, Willows is 'a prison from which no escape was possible. Where release could only mean one thing.'

Though the characters occasionally bemoan other comorbidities of ageing - sarcopenia can present a challenge when exhuming bodies in the dead of night-dementia is their greatest fear. Even death does not carry such dread: rather, most characters regard their own mortality with cheerful resignation. 'Life goes on, until it doesn't', comments Joyce as she sets about making a crumble.

Most of the characters in The Thursday Murder Club are in good health and able-bodied. Amongst the protagonists, only Ron has any hint of infirmity, refusing to use his stick out of pride. Those with comorbidities such as dementia or physical impairment are othered, locked away in the fearful Willows. When one murderer is confronted (at least six potential murderers have been identified by the novel's close), he gives his wife, bedbound and voiceless for several years, a fatal injection of fentanyl before committing suicide. It is hailed as a refusal to let her suffer any more, reflecting the popular prejudicial blindness to the implications of euthanasia of the severely disabled. There is little consideration of her autonomy or what pleasures she might yet experience.

Despite its framing of illness and infirmity as a dread horror, The Thursday Murder Club remains an optimistic and deeply pleasurable read. It portrays its ageing characters as warm, intelligent, capable adults, realising their potential anew. They have been united in a community, given an opportunity for new experiences and fresh pleasures. They talk and drink and solve crime, in the late summer sun. Joyce expresses her delight, 'Well, isn't this lovely, Ron? I never knew I liked beer. Imagine if I died at 70? I would never have known.'

\section{References}

1. Rowe JW, Kahn RL (1987) Human aging: usual and successful. Science 237:143-149

2. Richardson S, Karunananthan S, Bergman H (2011) I may be frail but I ain't no failure. Can Geriatr J 14:24

3. O'Neill D (2020) Generating guardians of the longevity dividend. Age Ageing 49:932-933

4. O’Neill D (2013) Simon's night. Gerontologist 53:1067-1069

5. Cohen-Shalev A, Marcus EL (2012) An insider's view of Alzheimer: cinematic portrayals of the struggle for personhood. Int $\mathbf{J}$ Ageing Later Life 7:73-96

6. Osman R (2020) The Thursday Murder Club. Viking, London

Publisher's Note Springer Nature remains neutral with regard to jurisdictional claims in published maps and institutional affiliations. 